\title{
GEOGRAPHICAL STUDIES OF THE FORMATION OF CULTURAL AND HISTORICAL LANDSCAPES OF ANCIENT RUSSIAN CITIES ALONG THE GREAT VOLGA WATERWAY
}

DOI: http://dx.doi.org/10.18509/GBP.2019.21

UDC: 991.5:[911.373.4:904(470)

\author{
Natalia Erman ${ }^{1}$ \\ Viacheslav Nizovtsev ${ }^{2}$ \\ ${ }^{1}$ S. I. Vavilov Institute for the History of Science and Technology of the \\ Russian Academy of Sciences, Russia \\ ${ }^{2}$ Lomonosov Moscow State University, Geographical faculty, \\ Department of Physical Geography and Landscape Science, Moscow, Russia
}

\begin{abstract}
The authors are developing conceptual and methodological basis for studying the role of the natural (landscape) factor in the multifactor processes of forming the cultural and historical landscapes of the ancient Russian cities that formed along the Upper Volga segment of the Great Volga historic waterway. The Upper Volga segment is considered as a single integral system (cultural and historical region). Research is conducted on the basis of a historical and geographical approach, on two hierarchical levels: a) at the regional level, where the cultural and historical region of the Upper Volga segment is explored and b) at the local level where historical centers of ancient Russian cities are explored (cultural and historical urban landscapes). The study sets out the features of the landscape structure of this region, the history of its economic development and the peculiarities of the formation of ancient Russian cities at the early stages of the functioning of this waterway.
\end{abstract}

Keywords: The Upper Volga Region, landscape, the Formation, Evolution.

\section{INTRODUCTION}

The formation and development of cultural and historical landscapes of ancient Russian cities is a natural result of evolutionary processes of a particular territory. Geographical studies of the basic patterns of the formation and evolution of urban landscapes in the initial stages of their formation, studies of the interaction of the city and landscape have been gaining more and more significant place in the scientific literature.

Scientific studies of the city and landscape are the most complete and diverse and they are especially well studied from a historical point of view. Many geographic aspects of modern urban landscapes have also been thoroughly studied. At the same time, with rare exceptions, there have not been associated historical and geographical studies of ancient Russian cities, and the studies of the basic patterns of the formation of the structure of urban landscapes in the early stages of their development have generally been at the initial stage.

An interdisciplinary approach to the study of a problem at the border area of the humanities and natural sciences such as history and geography is viewed as the most relevant at the present stage of the science development. A number of issues related to the understanding of the factors that led to the formation of the ancient Russian cities and the changes that took place within them are debatable and often not sufficiently 
substantiated. This primarily relates to the geography of ancient Russian cities, the determination of the influence of natural factors on them and, above all, the properties of their surrounding landscapes, which were the resource base for their formation, existence and development. It is sufficient to recall the ongoing controversy in the historical science about the "transfer" of ancient Russian cities, where there are hardly any arguments on the properties of the landscape structure as a factor of their development.

\section{HISTORIOGRAPHIC REVIEW}

Complex historical and geographical (landscape and historical in particular) studies of ancient cities with specific retrospective reconstructions of urban landscapes and their structures for the initial stages of their formation are rare in both the world and Russian science. There are a number of historical and geographical studies of ancient Russian cities, however their main difference is either a narrow component orientation or an absence of retrospective studies of the anthropogenic component in specific landscape conditions. In recent years, in landscape studies, considerable attention has been paid to the development of clear criteria for the identification and diagnosis of anthropogenically modified landscapes, including urban landscapes [2,3].

The problem of studying the formation and development of the Great Volga Route and the ancient Russian cities has received all-round coverage in the Russian historiography. Among the numerous works on the study of the Great Volga Route, the detailed monograph by I.V. Dubov [1] stands out. A huge array of publications is devoted to the study of ancient cities, including the cities of the Great Volga Route. Here, we can list the general works of historians (monographs, sections in monographs and articles) such as M.N. Tikhomirov, 2008 [12]; A.V. Cuza, 1989 [6]. There is also an abundant massive of sources that addresses the issues of urban planning and planning aspects of cities. Among these works there are the monographs of a complex plan by the famous urban geographer G.M. Lappo [7].

At the same time, there remain debatable questions about the origin of ancient Russian cities, the stages of the formation of urban landscapes and local differences. The question of the role of the natural factor and the landscape properties of the terrain in the formation of ancient Russian cities remains poorly studied. While the problems of the relations between the modern city and the landscape have been in the center of attention of scientists of different profiles (for example, the work by Vladimirov V.V., Mikulina E.M. and Yargina Z.N. [13] became classical), the historical aspect of this process and the development of methods of associated historical and geographical research of urban landscapes of the most ancient periods of our history are at the initial stage of development. It is also possible to mention the works concerning the historical and landscape aspect of the development of the ancient Russian cities of the Upper Volga region by E.U. Kolbovsky $[4,5]$. There are still controversial questions on the origin of the cultural and historical landscapes of ancient Russian cities, the stages of formation, local differences and features of their dynamics.

\section{METHODOLOGY AND METHODS}

The development of ancient Russian cities on historic waterways is determined by a combination of physiographic, socio-economic and historical factors. Therefore, their research should have a complex interlinked interdisciplinary historical and geographical character with specific retrospective reconstructions of urban landscapes and their 
structure for the initial stages of their formation. The methodological basis of the study is the historical and geographical approach, which includes the method of interlinked analysis of historical, archaeological and geographical materials with the preparation of a series of historical and geographical maps using the latest computer technologies and the creation of historical and geographical information databases.

Research is conducted on the basis of a historical and geographical approach, on two hierarchical levels: a) at the regional level, where the cultural and historical region of the Upper Volga segment is explored and b) at the local level where historical centers of ancient Russian cities are explored (cultural and historical urban landscapes). That is, the landscape differentiation of the territory with its inherent resource base was necessarily taken into account, and in key areas the study was carried out on certain parts of the landscape (morphological units), which served as the territorial basis for the formation of ancient Russian cities and for the formation of the structure of urban landscapes.

The main method of research was the combined analysis of historical, archaeological and geographical materials with the preparation of a series of historical and geographical maps using the latest computer technologies and the preparation of specific landscape and historical GIS. An important method of research was the landscape and historical mapping with the preparation of a series of multi-time maps of key areas reflecting the formation of urban landscapes at a certain historical stage in specific environmental conditions. All maps for each key section are created in electronic vector form for visualization in Mapinfo environment in a single coordinate system. All information in the maps is presented in the form of specific agreed map layers with numbered selections with attribute tables containing selection numbers and textual legends to them. All layers are integrated into the corresponding thematic map and a single historical and geographical GIS.

A particular attention within the framework of the historical and geographical approach is given to the historical and genetic and diachronic methods to identify the main stages of the periodization of the process of formation and evolution of cultural and historical landscapes, i.e. the study of the history of geographical objects (the establishment of their genesis and all stages of development) from the moment of their formation to the present, being the period of complete re-planning of the structure of urban landscapes (during the Soviet period of time).

\section{RESULTS AND CONCLUSION}

The natural and anthropogenic component of the evolution of urban landscapes is considered in a single specific space and time, and all research is carried out at the regional level (for the entire Upper Volga segment) and at the local level (for historical centers of cities). The Upper Volga segment of the Great Volga Route was selected as the object of detailed research. It was on this segment of the Great Volga Route that the system of ancient Russian cities was formed, the formation and development of which is directly related to the formation and functioning of this communicative way, which was the most important for the ancient Russian state. The main feature of the studied area is the unity and integrity of the natural and anthropogenic component, which was taking shape over a thousand-year period and represents at present an integral cultural and historical region. Natural and anthropogenic component of the evolution of urban landscapes are considered in a single specific space and time, and modern urban landscapes are considered as a kind of landscape historical systems, namely cultural and historical landscapes [8]. 
The results of the analysis of the settlement structure have showed that at the studied area of the historical waterways the following two main stages of the settlement and the economic development of the territory and the formation of the ancient Russian cities on them can be identified: from the VIII to X centuries (early) and from the X to XIII centuries (late).

The authors, relying on the long-term works of the Integrated Expedition to study the historical waterways of Russia, have established the peculiarities of the landscapes and their anthropogenic transformation at the early stages of their economic development [9, $10,11]$. Further, a comparative analysis of landscape, natural component and historicalgeographical maps of the area of historical water systems in combination with research in key areas allowed to establish some features of nature management, the formation of ancient Russian cities and the formation of settlement structure depending on the specifics of waterways and the landscape structure of the area. In the ancient Russian period, which was the period of the formation of the Great Volga trade route along the shores of lakes, the Volga river and its tributaries, a permanent and rather dense settlement network was formed. This region was becoming one of the key areas of the Slavic settlement and the formation of the ancient Russian state. Landscape analysis of the spatial distribution of historic Upper Volga cities showed that at an early stage in the Old Russian period, places for building cities (proto-cities) were usually chosen on the most important sections of the waterway, taking into account their safety, with a relatively simple landscape structure, on low relief elements. They were located mainly on gently sloping surfaces of low above-floodplain or lake terraces, areas of low valley outwash plains, rarely on the near-valley slopes of inter-river plains and sometimes on high floodplains emerging from the flooding regime.

Later, cities began to be laid mainly in the river valleys on steep banks on the relatively isolated sites of valley outwash plains (most often low valley outwash plains, which corresponds to the third above-flood terrace), cut from the sides by steeply cut valleys of small daughter rivers or valleys of the beam type. Settlements outside fortresses were located at lower levels: on the second and first floodplain terraces, adjacent to these parts of the valley outwash plains. Since almost all the cities were self-sufficient in food or formed as centers of the surrounding agricultural areas, when choosing the location of the city, preference was given to ecotone territories with a complex landscape structure and rich resource base that allowed the first settlers to conduct a flexible complex economy. Therefore, the study sets out the features of the landscape structure of this region, the history of its economic development and the peculiarities of the formation of ancient Russian cities at the early stages of the functioning of this waterway. As a result of the research, it was concluded that the spatial differences in the location of cities are due to provincial-zonal conditions and their position in specific landscape conditions, which is often a decisive factor in their formation and development.

\section{ACKNOWLEDGMENT}

The work is performed under the project of Russian Foundation for Basic Research № 18-311-00222 


\section{REFERENCES}

[1] Dubov I.V. Great Volga Way. Leningrad, Russia, 1989, pp 257.

[2] Erman N.M., Nizovtsev V.A. Landscape and Historic Prerequisites of the Origin of the Town of Smolensk, Izvestia: Herzen University Journal of Humanities \& Science. Saint Petersburg, Russia, vol. 153(2), pp117-121, 2012.

[3] Graves I.V., Graves K.K., Nizovtsev V.A., Erman N.M. Landscape conditions of formation of ancient towns, Landscape-ecological support for rational nature management and sustainable development, Tumen, Russia, vol 2, pp 222-225, 2017.

[4] Kolbovsky E.U. History and ecology of landscapes of the Yaroslavl Volga region Yaroslavl, Russia. 1993. p.114

[5] Kolbovsky E.U. The cultural landscape of the Upper Volga, Historical geography of Russia, Tver, Russia, pp 5-25, 1995.

[6] Kuza A.V. Small Cities of Ancient Russia. Moscow, Russia, 1989, 168c.

[7] Lappo G.M. Cities of Russia: a Geographer's View, Moscow, Russia, 2012, p.514.

[8] Nizovtsev V.A. Anthropogenic landscape genesis: the subject and goals of investigations, Vestnik Moskovskogo Unviersiteta, Seriya Geografiya, Russia, vol.1, pp. 26-30, 1999.

[9] Nizovtsev V.A, Postnikov A.V., Snytko V.A., Frolova N.L., Chesnov V.M., Shirokov R.S., Shirokova V.A. Historical waterways of the North of Russia (17th - 20th century) and their role in changing environmental conditions. Field studies: actual state, results, perspectives. Moscow, Russia, 2009, p.298.

[10] Nizovtsev V.A. The formation of settlement structure in "Ilmen-Dnepr corridor" of historical waterway "From the Varangians to the Greeks", Bulletin of the Novgorod branch of the Russian Academy of National Economy and Public Administration, vol. 1, pp 149-158, 2013.

[11] Nizovtsev V.A., Erman N.M. The history of the economic development of landscapes of the Upper Volga section on the Great Volga Route, Landscape-ecological state of the regions of Russia, Voronezh, Russia, 2015. pp. 154-158.

[12] Tikhomirov M.N. Old Russian cities, Moscow, Russia, 2008, p.350.

[13] Vladimirov V.V., Mikulina E.M., Yargina Z.N. City and landscape. Problems, constructive tasks and solutions, Moscow, Russia, 1986, p.238. 